\title{
MAIZE YIELD AND ITS ATTRIBUTES AS AFFECTED BY RATES OF NITROGEN AND ORDINARY SUPER PHOSPHATE INCORPORATED WITH CHICKEN MANURE UNDER AL-ARISH SANDY SOIL CONDITIONS \\ Wahba, H. W. A.; A. A. Rahmou and K. A. Khatab \\ Soils, Water and Environment Research Institute, ARC, Giza
}

\begin{abstract}
Two field experiments were carried out at the experimental farm of Al-Arish Agricultural Research Station, Governorate of South Sinai, Agricultural Research Centre (ARC) in summer seasons of 2006 and 2007 to investigate the effectiveness of different rates of nitrogen fertilizer $60,90,120 \mathrm{~kg} / \mathrm{fed}$ and ordinary super phosphate zero, $15,30 \mathrm{~kg} \mathrm{P} \mathrm{O}_{5} / \mathrm{fed}$ incorporated with $10 \mathrm{~m}^{3}$ chicken manure/fed on yield of maize (Three Way Cross 324 cultivar) and its attributes under Al-Arish soil conditions. The results showed that application of chicken manure at the rate of $10 \mathrm{~m}^{3} / \mathrm{fed} \mathrm{had}$ similar effect as application of 15 or $30 \mathrm{~kg} \mathrm{P} \mathrm{P}_{5} / \mathrm{fed}$ together with $10 \mathrm{~m}^{3}$ chicken manure/fed in kernel yield and its relevant attributes. Application of $15 \mathrm{~kg} \mathrm{P}_{2} \mathrm{O}_{5} / \mathrm{fed}+$ $10 \mathrm{~m}^{3}$ chicken manure/fed had significant effect on plant height and this combined rate was better than $30 \mathrm{~kg} \mathrm{P} \mathrm{O}_{5} / \mathrm{fed}+10 \mathrm{~m}^{3}$ chicken manure/fed in kernel yield and its relevant attributes. The interaction of the two factors under investigation had insignificant effect on the agronomic parameters investigated in these two experiments. Increasing nitrogen rate from 60 to $90 \mathrm{~kg} / \mathrm{fed}$ caused positive significant effect on $\mathrm{N}$ and $\mathrm{P}$ contents in kernels. Additional increase in $\mathrm{N}$ rate caused significant effect on $\mathrm{P}$ and $\mathrm{K}$ contents in kernels.
\end{abstract}

Keywords: Maize, yield attributes, nitrogen rates, ordinary super phosphate, Chicken manure, Al-Arish sandy soil

\section{INTRODUCTION}

Maize (Zea mays L.) is the main summer crop grown in Egypt for man, livestock and industry. It is one of the main sources of food in the desert community. This plant responds very well to organic fertilizers (Reeves, 1991) and maize $\mathrm{N}$ uptake was greater with residues than with $\mathrm{N}$ fertilizer (Reeves et al., 1997). Hence, the idea of the current investigation stands on using chicken manure as a source of organic fertilizer to remedy the two major problems in sandy soil of Al-Arish i.e. inadequate water retention and low fertility status. Also, treatments in this investigation included nitrogen and phosphorus fertilizer rates to study to what extent they contribute to producing a promising maize yield under Al-Arish desert environment. Many investigators have studied the effect of $\mathrm{N}$ and $\mathrm{P}$ on maize yield such as AbuGrab et al, (1997), Faisal and Shalaby (1998), Ismail et al, (1999) and ElBana (2001) who emphasized that maize grain and stalk yields were increased significantly by increasing nitrogen levels $(60,90$ and 120; 0, 45. 90, 135 and 180;0, 80, 105 and 130 and 60, 90 and $120 \mathrm{~kg} \mathrm{~N} / \mathrm{fed}$ respectively. Meanwhile, Kang and Yunusa (1977) reported that the root density of maize was increased with $P$ application. They added that broadcast, band and hill methods of $\mathrm{P}$ application were equally effective in supplying adequate $P$ to maize crop at $P$ rates of $20 \mathrm{~kg} \mathrm{P} /$ ha on the Egbeda soil. Steffen et al, (2001) emphasized that P plays a central role as reactant 
and effector molecule in plant cell metabolism and its low availability often limits plant growth. Plants have evolved an array of molecular and morphological adaptations to cope with $\mathrm{P}$ limitation, which include dramatic changes in gene expression and root development to facilitate $P$ acquisition and recycling. Xu Tang et al, (2008) illustrated that $P$ fertilization increased the average crop yield of maize by (85\%) over 15 years. They concluded that $\mathrm{P}$ content in maize was $2.1 \mathrm{~g} / \mathrm{kg}$ with higher values with control, NP, and NPK treatments and to produce 1 ton of grain maize crop required $3.1 \mathrm{~g} \mathrm{"P"} / \mathrm{kg}$.

Meanwhile, several investigators emphasized that incorporating organic manures into soil as a fertilizer led to decrease soil $\mathrm{pH}$ with the result that solubility and availability of some nutrients to plants were increased (Salem 1986). Imara and Hammissa emphasized that maize grain $\mathrm{N}$ uptake was greater with organic manure than with inorganic chemical $\mathrm{N}$ fertilizer. Organic manures were also involved in fertilization of plants in almost all countries around the world due to their beneficial effects on physical, chemical and biological characteristics of the soils, consequently, growth and production of plants were increased (Youssef et al, 2001). Mahmoud et al., (2004) emphasized that organic fertilization significantly increased rice yield and its components than mineral fertilization. Recently, Acande et al, (2005) emphasized that complementary application of Sokoto and Ogun rock phosphates with poultry manure increased maize plant height by 12 and 6 , and 19 and $8 \%$, respectively. They added that percent phosphorus contents in maize and cowpea leaf tissues increased respectively by $33 \%$ and 22 , and 22 and $25 \%$ in 2000, and by 25 and 6 , and 16 and $18 \%$, respectively in 2001 . They added also that maize grain yield was increased by 33 and 26, and 18 and $25 \%$, respectively, while that of cowpea was increased by 25 and 3 , and $38 \%$ in 2000 and 2001 , respectively when compared with application of rock phosphate alone.

The purpose of the current investigation is to study the effectiveness of rates of nitrogen and ordinary super phosphate incorporated with chicken manure on maize yield and its attributes under Al-Arish soil conditions.

\section{MATERIALS AND METHODS}

Two-field experiments were conducted at the experimental farm of Al-Arish Agricultural Research Station at Al-Arish, Governorate of South Sinai, Agricultural Research Centre (ARC) in 2006 and 2007 to investigate the effectiveness of different rates of nitrogen fertilizer and ordinary super phosphate (OSP) incorporated with chicken manure on yield of maize (Three Way Cross 324 cultivar) and its attributes under Al-Arish soil conditions. Representative soil samples from the experimental sites and chicken manure were taken to determine some physical and chemical properties of the soil and chicken manure according to Chapman and Pratt (1961). Results are shown in Table (1) and (2):

Maize grains were planted by hand in summer of 2006 and 2007. The two experiments were carried out in a split plot design with three replicates and each split plot area was $10.5 \mathrm{~m}^{2}$ in which nitrogen levels 60 , $90,120 \mathrm{~kg} \mathrm{~N} /$ fed were assigned in main plots whereas ordinary super 
phosphate plus chicken manure treatments were placed in sub-plots. Nitrogen fertilizer was side banded in the form of ammonium sulphate 20,5\% $\mathrm{N}$ in two equal doses; after 15 days from planting and 15 days later from the first dose. Ordinary Super phosphate $\left(15.5 \% \mathrm{P}_{2} \mathrm{O}_{5}\right)$ was incorporated with

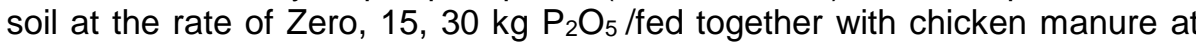
$10 \mathrm{~m}^{3}$ in all sub-plots while preparing seed bed. Potassium sulphate $(48 \%$ $\mathrm{K}_{2} \mathrm{O}$ ) was broadcast to all experimental plots as a source of $\mathrm{K}$ before planting. The experimental sites were under drip irrigation system and wheat was preceding maize in the experimental area.

Table (1): Some physical and chemical properties of the tested soil.

\begin{tabular}{|c|c|c|c|c|c|c|c|c|c|c|c|}
\hline Seasons & $\begin{array}{c}\text { O.M } \\
\%\end{array}$ & $\begin{array}{c}\text { Coarse } \\
\text { sand \% }\end{array}$ & $\begin{array}{c}\text { Fine } \\
\text { sand \% }\end{array}$ & Silt \% & $\begin{array}{c}\text { Soil } \\
\text { texture }\end{array}$ & $\begin{array}{c}\mathrm{CaCO}_{3} \\
\%\end{array}$ & $\begin{array}{c}\mathrm{pH} \\
\mathbf{( 1 : 2 . 5} \\
\text { Susp) }\end{array}$ & \multicolumn{2}{|c|}{$\begin{array}{c}\text { E.C dSm } \\
\text { (soil paste } \\
\text { extract) }\end{array}$} & $\begin{array}{c}\text { Available macro } \\
\text { nutrients (ppm) }\end{array}$ \\
\hline 2006 & 0.01 & 78.18 & 16.19 & 2.40 & Sand & 2.50 & 8.11 & 1.25 & 21 & 7 & $\mathbf{P}$ \\
\hline 2007 & 0.01 & 77.85 & 16.65 & 2.70 & Sand & 2.43 & 8.12 & 1.13 & 19 & 9 & 51 \\
\hline
\end{tabular}

Table (2): Chemical analysis of chicken manure,(CM).

\begin{tabular}{|c|c|c|c|c|c|c|c|c|c|c|c|c|}
\hline \multirow[t]{2}{*}{ C } & \multirow{2}{*}{$\begin{array}{l}\text { Total } \\
\mathrm{N} \%\end{array}$} & \multirow{2}{*}{$\begin{array}{l}\text { C: } \mathbf{N} \\
\text { Ratio }\end{array}$} & \multirow[t]{2}{*}{ O.M \% } & \multirow{2}{*}{$\begin{array}{l}\text { Total } \\
\text { P \% }\end{array}$} & \multirow{2}{*}{$\begin{array}{c}\text { Total K } \\
\%\end{array}$} & \multirow{2}{*}{$\begin{array}{c}\text { Available } \\
\mathrm{N} \mathrm{ppm}\end{array}$} & \multirow{2}{*}{$\mid \begin{array}{c}\text { Available } \\
\text { P ppm }\end{array}$} & \multirow{2}{*}{$\begin{array}{c}\text { Available } \\
\mathrm{K} \mathrm{ppm}\end{array}$} & \multicolumn{4}{|c|}{$\begin{array}{l}\text { Available micro } \\
\text { nutrients (ppm) }\end{array}$} \\
\hline & & & & & & & & & & \begin{tabular}{l|l}
$\mathrm{Zn}$ & 1
\end{tabular} & $\mathrm{Mn}$ & $\mathrm{Cu}$ \\
\hline 8 & \begin{tabular}{|l|}
2.14 \\
\end{tabular} & $12: 1$ & $\overline{4}$ & 158 & 2.01 & 1170 & 516 & 800 & 5.350 & \begin{tabular}{l|l}
0.35 & \\
\end{tabular} & 1.03 & 00 \\
\hline
\end{tabular}

At harvest after 120 days from planting, plants at the dripping hoses in the middle of each plot were harvested and collected to estimate yield and its attributes. Data were tabulated and subject to statistical treatments according to Steel and Torrie (1980).

\section{RESULTS AND DISCUSSION}

\section{1- Effect of $\mathbf{N}$ rates on kernel yield and its relevant attributes:}

Data in Table (3) show that plant height, ear length, diameter and weight, No. of rows/ear and kernel yield were insignificantly affected by $\mathrm{N}$ rates, which means that application of $\mathrm{N}$ at the rate of $60 \mathrm{~kg} / \mathrm{fed}$ is more economically favorable than the other two rates. These results are in agreement with those of Abu-Grab et al, (1997), Faisal and Shalaby (1998), Ismail et al, (1999) and El-Bana (2001), moreover, Gebraiel et al, (2005) supported this conclusion while studying maize growth and yield as affected by nitrogen, potassium and zinc fertilization.

\section{2- Effect of $(P+$ chicken manure) on kernel yield and its relevant} attributes:

Data in Table (3) and Fig. (1) also reveal that application of chicken manure at the rate of $10 \mathrm{~m}^{3} / \mathrm{fed}$ only gave a significant plant height that surpassed treatments viz. ( $15 \mathrm{~kg} \mathrm{P} \mathrm{O}_{5} / \mathrm{fed}+10 \mathrm{~m}^{3}$ chicken manure/fed) or (30 $\mathrm{kg} \mathrm{P}_{2} \mathrm{O}_{5} / \mathrm{fed}+10 \mathrm{~m}^{3}$ chicken manure/fed) indicating that the favorable amount of available $P$ in chicken manure had a significant contribution to supplying adequate $\mathrm{P}$ to maize crop (Kang and Yunusa, 1977), to the central role as reactant and effector molecule in plant cell metabolism and to the root development to facilitate $\mathrm{P}$ acquisition and recycling (Steffen Abel et al, 2001) 
Wahba, H. W. A. et al.

Table (3): Response of maize grain yield and some relevant attributes as combined analysis of variance of 2006 and 2007 seasons

\begin{tabular}{|c|c|c|c|c|c|c|c|c|}
\hline $\begin{array}{c}\text { Main } \\
\text { plot } \\
\text { kg } \\
\text { N/fed }\end{array}$ & $\begin{array}{c}\text { Sub plot kg } \mathrm{P}_{2} \mathrm{O}_{5} / \mathrm{fed} \\
+10 \mathrm{~m}^{3} \mathrm{C} . \mathrm{M} / \mathrm{fed}\end{array}$ & $\begin{array}{c}\text { Plant } \\
\text { heightt } \\
\mathrm{cm}\end{array}$ & $\begin{array}{c}\text { Ear } \\
\text { length } \\
\mathbf{c m}\end{array}$ & $\begin{array}{c}\text { Ear } \\
\text { diameter } \\
\text { cm }\end{array}$ & $\begin{array}{c}\text { No. of } \\
\text { rows/ } \\
\text { ear }\end{array}$ & $\begin{array}{l}\text { Ear } \\
\text { wt.g }\end{array}$ & $\begin{array}{l}\text { Kernel } \\
\text { wt./ear }\end{array}$ & $\begin{array}{c}\text { Kernel } \\
\text { yield } \\
\text { arddab } \\
/ \\
\text { fed } \\
\end{array}$ \\
\hline \multirow{3}{*}{60} & CM only & 139.15 & 19.22 & 5.79 & 14.00 & 191.86 & 177.56 & 18.13 \\
\hline & $15 \mathrm{~kg} \mathrm{P}_{2} \mathrm{O}_{5} / \mathrm{fed}+\mathrm{CM}$ & 139.85 & 19.05 & 5.91 & 14.00 & 196.65 & 182.46 & 17.45 \\
\hline & $30 \mathrm{~kg} \mathrm{P} \mathrm{P}_{5} / \mathrm{fed}+\mathrm{CM}$ & 137.35 & 20.42 & 5.46 & 15.00 & 212.92 & 197.47 & 19.53 \\
\hline & Average $\mathrm{N}$ & 138.78 & 19.59 & 5.72 & 14.33 & 200.48 & 83 & 18.37 \\
\hline \multirow{3}{*}{90} & CM only & 144.80 & 19.05 & 5.46 & 14.50 & 186.88 & 173.46 & 18.05 \\
\hline & $15 \mathrm{~kg} \mathrm{P}_{2} \mathrm{O}_{5} / \mathrm{fed}+\mathrm{CM}$ & 133.90 & 18.78 & 5.41 & 14.50 & 184.00 & 170.24 & 17.59 \\
\hline & $30 \mathrm{~kg} \mathrm{P} 2 \mathrm{O}_{5} / \mathrm{fed}+\mathrm{CM}$ & 139.40 & 18.97 & 5.64 & 14.00 & 195.47 & 181.05 & 18.42 \\
\hline & Average $\mathrm{N}$ & 139.37 & 18.93 & 5.50 & 14.33 & 188.78 & 174.92 & 18.02 \\
\hline \multirow{3}{*}{120} & CM only & 145.50 & 19.17 & 5.65 & 14.50 & 221.40 & .33 & 17.28 \\
\hline & $15 \mathrm{~kg} \mathrm{P} \mathrm{P}_{2} / \mathrm{fed}+\mathrm{CM}$ & 138.15 & 18.31 & 5.67 & 14.50 & 58 & 175.59 & 17.41 \\
\hline & $30 \mathrm{~kg} \mathrm{P} 2 \mathrm{O}_{5} / \mathrm{fed}+\mathrm{CM}$ & 142.05 & 18.28 & 5.71 & 14.50 & 19015 & 172.51 & 17.84 \\
\hline & Average $\mathrm{N}$ & 141.90 & 18.59 & 5.67 & 14.502 & 200.04 & \begin{tabular}{|l|}
175.14 \\
\end{tabular} & 17.51 \\
\hline \multirow{3}{*}{$\begin{array}{c}\text { Avera } \\
\text { ge } \mathrm{P}_{+} \\
\mathrm{CM}\end{array}$} & CM only & $143.15 \mathrm{a}$ & 19.17 & 5.63 & 14.332 & 200.05 & \begin{tabular}{|l|}
176.11 \\
\end{tabular} & 17.82 \\
\hline & $15 \mathrm{~kg} \mathrm{P} \mathrm{P}_{2}$ & $137.30 \mathrm{~b}$ & 18.71 & 5.66 & 14.33 & & 09 & 17.49 \\
\hline & $30 \mathrm{~kg} \mathrm{P} \mathrm{P}_{2} \mathrm{O}_{5} / \mathrm{fed}+\mathrm{CM}$ & $139.60 \mathrm{ab}$ & 19.22 & 5.60 & 14.50 & 199.51 & \begin{tabular}{|l|}
183.68 \\
\end{tabular} & 18.60 \\
\hline \multicolumn{9}{|c|}{ LSD } \\
\hline & $\mathrm{N}$ & N.S & N.S & N.S & N.S & N.S & N.S & N.S \\
\hline & $\mathrm{P}+\mathrm{CM}$ & 4.65 & N.S & N.S & N.S & N.S & N.S & N.S \\
\hline & $\mathrm{NX}(\mathrm{P}+\mathrm{CM})$ & N.S & N.S & N.S & N.S & N.S & N.S & N.S \\
\hline
\end{tabular}

Fig. (1): Effect of nitrogen rates and ordinary super phosphate with chicken manure and maize yield 
This result is also in agreement with that found by (Acande et al, 2005). The superiority of chicken manure mentioned above may be related to the decrease of soil $\mathrm{pH}$ leading to more solubility and availability of some macro and micro-nutrients to plants as mentioned by (Salem 1986) and to the beneficial effects on physical, chemical and biological characteristics of the soils that reflected positively to plant growth as mentioned by (Youssef et al, 2001). Mahmoud et al. (2004) supported these results while studying the response of maize to some integrated mineral and biofertilization treatments on different soils of Egypt.

Concerning the effect of $\mathrm{N} \times(\mathrm{P}+\mathrm{CM})$ interaction on these agronomic parameters, the results indicated that this interaction had insignificant effect.

\section{3- Effect of $\mathrm{N}$ rates on $\mathrm{N}, \mathrm{P}$ and $\mathrm{K}$ contents in kernels:}

Data in Table (4) and Fig. (2) illustrate that increasing $N$ rates from 60 to $90 \mathrm{~kg} / \mathrm{fed}$ significantly increased $\mathrm{N}$ and $\mathrm{P}$ contents in kernels due to the increase in available $\mathrm{N}$ in maize root vicinity leading to improving plant growth and dry matter accumulation as reported by Fan and Moshe (2002). Meanwhile Wahba (2003) confirmed this conclusion on investigating the response of some high-yielding maize cultivars to mineral and bio $\mathrm{N}$ fertilization. On the other hand, additional application of $\mathrm{N}$ rates up to 120 $\mathrm{kg} / \mathrm{fed}$ caused significant increase in $\mathrm{P}$ and $\mathrm{K}$ contents only. Similar result was reported by El-Bana (2001).

Table (4): N, P and K contents in kernels as affected by N and OSP with chicken manure as combined analysis of variance of 2006 and 2007 seasons

\begin{tabular}{|c|c|c|c|c|}
\hline \multirow{2}{*}{ Main plot kg N/fed } & \multirow{2}{*}{$\begin{array}{c}\text { Sub plot kg } \mathrm{P}_{2} \mathrm{O}_{5} / \mathrm{fed}+ \\
10 \mathrm{~m}^{3} \mathrm{C} . \mathrm{M} / \mathrm{fed}\end{array}$} & \multicolumn{3}{|c|}{ Control } \\
\hline & & $\mathbf{N}$ & $\mathbf{P}$ & $\mathbf{K}$ \\
\hline \multirow{3}{*}{60} & CM only & 1.83 & 0.41 & 0.28 \\
\hline & $15 \mathrm{~kg} \mathrm{P} \mathrm{O}_{5} / \mathrm{fed}+\mathrm{CM}$ & 1.85 & 0.44 & 0.31 \\
\hline & $30 \mathrm{~kg} \mathrm{P} \mathrm{O}_{5} / \mathrm{fed}+\mathrm{CM}$ & 1.88 & 0.48 & 0.32 \\
\hline \multicolumn{2}{|c|}{ Average $\mathrm{N}$} & $1.85 \mathrm{~b}$ & $0.44 \mathrm{c}$ & $0.30 \mathrm{~b}$ \\
\hline \multirow{3}{*}{90} & CM only & 1.89 & 0.44 & 0.31 \\
\hline & $15 \mathrm{~kg} \mathrm{P} \mathrm{O}_{5} / \mathrm{fed}+\mathrm{CM}$ & 1.90 & 0.49 & 0.32 \\
\hline & $30 \mathrm{~kg} \mathrm{P} \mathrm{O}_{5} / \mathrm{fed}+\mathrm{CM}$ & 1.95 & 0.52 & 0.34 \\
\hline \multicolumn{2}{|c|}{ Average $\mathrm{N}$} & $1.91 \mathrm{a}$ & $0.48 \mathrm{~b}$ & $0.32 \mathrm{~b}$ \\
\hline \multirow{3}{*}{120} & CM only & 1.91 & 0.46 & 0.33 \\
\hline & $15 \mathrm{~kg} \mathrm{P} \mathrm{O}_{5} / \mathrm{fed}$ & 1.94 & 0.53 & 0.35 \\
\hline & $30 \mathrm{~kg} \mathrm{P} \mathrm{O}_{5} / \mathrm{fed}+\mathrm{CM}$ & 1.97 & 0.58 & 0.38 \\
\hline \multicolumn{2}{|c|}{ Average $\mathrm{N}$} & $1.94 \mathrm{a}$ & $0.52 \mathrm{a}$ & $0.35 \mathrm{a}$ \\
\hline \multirow{3}{*}{ Average $\mathrm{P}+\mathrm{CM}$} & CM only & 1.88 & $0.44 \mathrm{~b}$ & 0.31 \\
\hline & $15 \mathrm{~kg} \mathrm{P} \mathrm{O}_{5} / \mathrm{fed}+\mathrm{CM}$ & 1.90 & $0.49 \mathrm{a}$ & 0.33 \\
\hline & $30 \mathrm{~kg} \mathrm{P}_{2} \mathrm{O}_{5} / \mathrm{fed}+\mathrm{CM}$ & 1.93 & $0.53 \mathrm{a}$ & 0.35 \\
\hline \multicolumn{5}{|c|}{ LSD } \\
\hline & $\mathrm{N}$ & 0.05 & 0.03 & 0.03 \\
\hline \multicolumn{2}{|c|}{$\mathrm{P}+\mathrm{CM}$} & N.S & 0.04 & N.S \\
\hline \multicolumn{2}{|c|}{$\mathrm{N} X(\mathrm{P}+\mathrm{CM})$} & N.S & N.S & N.S \\
\hline
\end{tabular}


Wahba, H. W. A. et al.

\section{4- Effect of $(P+C M)$ on $N, P$ and $K$ contents in kernels:}

Data in Table (4) and Fig. (2) demonstrate that increasing the rate of OSP from zero to $15 \mathrm{~kg} \mathrm{P}_{2} \mathrm{O}_{5} / \mathrm{fed}$ together with $10 \mathrm{~m}^{3} / \mathrm{fed}$ chicken manure significantly raised the content of $P$ in kernels. This result was in conformity with that achieved by Acande et al, (2005) and Xu Tang et al, (2008). Meanwhile additional application of $P$ i.e. $30 \mathrm{~kg} \mathrm{P} \mathrm{O}_{5} / \mathrm{fed}+10 \mathrm{~m}^{3} \mathrm{CM} / \mathrm{fed}$ brought about insignificant effect on $\mathrm{P}$ and $\mathrm{K}$ contents in kernels.

Concerning the $\mathrm{N} \times(\mathrm{P}+\mathrm{CM})$ on the abovementioned nutritional contents in kernels, the results herein showed that this interaction had insignificant effect on N, P and K contents in kernels. 
In the light of the results of the current investigation, in the limits of results of analysis of soil samples and chicken manure and the nature of the experimental sites, it could be concluded that chicken manure as a source of organic fertilization should be used at least to replace a considerable part of mineral fertilizers. Moreover, we could not only reduce costs of agriculture but we can also improve yield quality.

\section{REFERENCES}

Abu-Grab, O. S.; F. A. El-Kady and A. A. Darwish (1997): Response of some maize cultivars to nitrogen fertilization under north and middle delta conditions. Annals of Agric. Sci. Moshtohor. 35: 1-14.

Acande, M.O.; J. A. Adediran and F. I. Oluwatoginbo (2005): Effects of rock phosphate amended with poultry manure on soil available $\mathrm{P}$ and yield of maize and cowpea. African Journal of Biotechnology, Vol. 4(5), pp 444-448.

Kang, B. T. and M. Yunusa (1977): Effect of Tillage methods and phosphorus fertilization on maize in the humid tropics. Agron, J. 69: 291-294.

Chapman, S. R. and P. F. Pratt (1961): Methods of Analysis of Soils, Plant and Water. University of California, $317 \mathrm{pp}$ (Book).

El-Bana, A. Y. A. (2001): Effect of nitrogen fertilization and stripping leaves on yield and yield attributes of two maize (Zea mays $L$ ) hybrids. Zagazig J. Agric. Res., 28: 579-596.

Faisal, R. I. I. and S. A. Shalaby (1998): Effect of organic manure and nitrogen fertilization on growth of maize under sprinkler irrigation system. Egypt J. Appl. Sci. 13: 114-129.

Fan, L. and S. Moshe (2002): Response of maize to foliar vs. soil application of nitrogen, phosphorus and potassium fertilizers. J. Plant Nutrition, 25: 2333-2342.

Gebraiel, M. Y; M. N. Gohar; F. S. Salem and H. W. A. Wahba (2005): Vegetative growth and yield of maize (Zea maize L.) as affected by nitrogen, potassium and zinc fertilization. Egypt J. Appl. Sci. 20 (2B) 2005.

Imara, Z. M and A. M. Hamissa (2000): Effect of plow types, plowing depth, organic manure and $\mathrm{N}$ fertilization on corn yield. Misr J. Ag. Eng., 17(1), January.

Ismail, S. A.; M. R. Morsy; S. S. Awad and F. S. Salem (1999): Effect of some maize varieties, nitrogen fertilization levels and zinc application on grain and stalk yields, total $\mathrm{N}$ and $\mathrm{Zn}$ uptake and protein content. Fayoum J. Agric. Res. And Dev., 1: 57-68.

Mahmoud, Awatef A.; Magda A. Ewais; Amina M. Abd El-Latif and A. A. ElMasry (2004): Effect of using organic and inorganic fertilization and inoculation with azolla efficiency on yield and quality of rice crop. Egypt J. Appl. Sci., 19 (5).

Reeves, M. (1991): Nitrogen-mediated interaction in legume non-legume intercropping systems. Ph. D. diss. Univ. of Michigan, Ann Arbar (Diss. Abstr. 91-35680). 
Reeves, M; Rattan Looal; Torry Logan and Jucun Sigaran (1997): Soil nitrogen and carbon response to maize cropping system, nitrogen source and tillage. Soil Sci. Soc. Am. J., Vol. 61:1387-1391.

Salem, N. M. M. (1986): Agro-chemical aspects related to the use of conditions and organic wastes in soils. Ph. D. Thesis, Fac. Agric. Sci. Rijksuniv Gent. Belgium.

Steel, R. G. D. and H. Torrie (1980): Principles and procedures of statistics. McGrew Hill Book Co. New York.

Steffen Abel; Carla A. Ticconi and Carla A. Delatorre (2001): Phosphate sensing in higher plants. Physiologia Plantarum Vol. 115, Issue 1, 1-8.

Wahba, H. W. A (2003): Response of some high-yielding maize cultivars to mineral and bio $\mathrm{N}$ fertilization. Ph. D. Thesis. Fac. of Agric, Moshtohor, Zagazig University, Banha Branch.

Xu Tang, Junei Li, Yibing Ma, Xiying Hao and Xiuying Li (2008): Phosphorus efficiency in long term (15 years) wheat-maize cropping systems with various soil climate conditions. Field Crops Research, Vol. 108, Issue3, 231-237.

Youssef, A. M; A. H. M. El-Fouly; M. S. Youssef and S. A. Mohamedien (2001): Effect of using organic and chemical fertilizers in fertigation system on yield and fruit quality of tomato. Egypt J. Hot. 28: (1), 59-77.

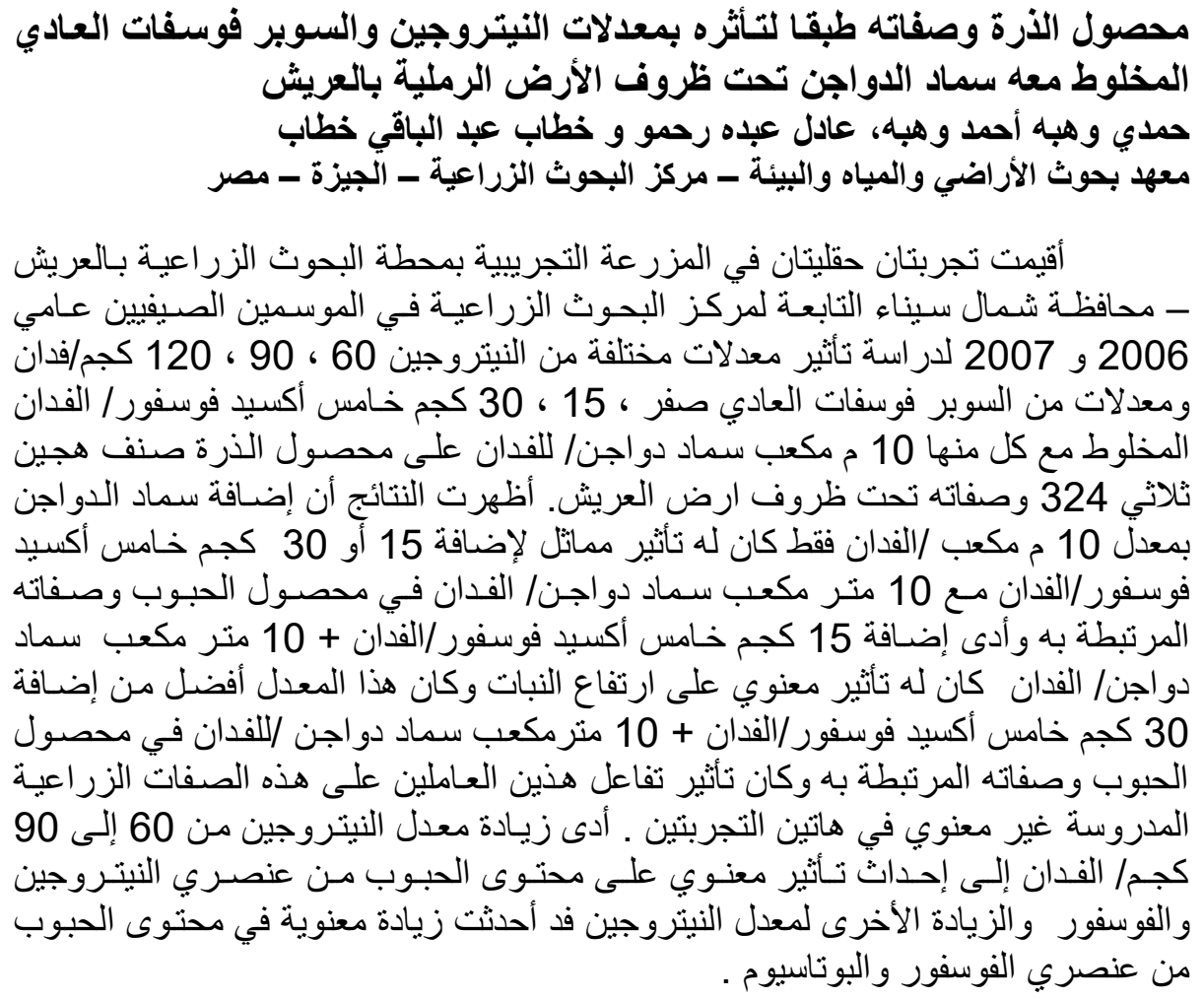

